\title{
Pension Accounting: The Changing Landscape Of Corporate Pension Benefits
}

Terrye A. Stinson, Southern Arkansas University, USA

J. David Ashby, Southern Arkansas University, USA

Kimberly M. Shirey, Southern Arkansas University, USA

\begin{abstract}
This paper discusses recent changes in the generally accepted accounting principles related to accounting for defined benefit pension plans. SFAS 158 imposes new rules related to calculating net pension assets or liabilities and increases the likelihood that companies may report net pension liabilities. This paper looks at a sample of Fortune 100 companies to determine the effect of implementing SFAS 158 on the reported funding status for defined benefit plans, and then tracks the reported pension status from 2005 through 2009. Contrary to expected results, the funding status did not deteriorate following implementation of SFAS 158. The ensuing economic meltdown in 2008 and 2009, however, resulted in more companies reporting pension liabilities.
\end{abstract}

Keywords: Pension Accounting; Defined Benefit Pension Plans

\section{INTRODUCTION}

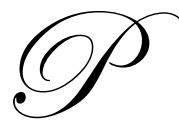

ostretirement benefits, specifically pension benefits, pose significant problems for employers and cause concern for millions of baby boomers who are approaching retirement age. Recent changes in the pension landscape impact employers in several ways. First, pension benefits continue to be a critical issue from a human resource perspective. Employees list retirement benefits as one of the primary considerations in taking a job (Dennis, 2006), but publicity about pension plan failures creates obvious concerns for many employees. Second, recent changes in pension regulations create new considerations for employers. During the last five years, employers faced new government regulation under the Pension Protection Act (PPA) of 2006 and faced new accounting rules in SFAS 158, Employers' Accounting for Defined Benefit Pension and Other Postretirement Plans (FASB, 2006). Adding to the complexities, U.S. financial markets have experienced increased volatility, impacting the $\$ 5$ trillion market segment associated with pension plans.

While most companies continue to offer retirement plans for employees, there has been a significant change in the types of benefits offered. Over the last 20 years, many companies have moved away from traditional defined benefit plans, where employers bear market risk and promise certain benefits to retirees, and have adopted defined contribution plans, where employees bear market risk and employers merely provide contributions to the plan. In 1985, over 112,000 companies offered insured defined benefit (DB) plans; by 2005, there were less than 30,000 plans (Milevsky \& Song, 2010, 906-907). According to one study, 83 percent of companies offered DB plans in 1990 and only 45 percent offered DB plans in 2005 (Apostolou and Crumbley, 2006, 26). On the other hand, since 1970, the number of individuals participating in defined contribution (DC) plans has increased from 15 million to over 62 million.

The shift from DB plans to DC plans may be the result of several influencing factors, but the complexity of accounting for DB plans is certainly a key factor. Employers with DB plans must calculate projected obligations for future pension benefits and estimate present values of those obligations. Employers with underfunded plans have liabilities, which are reported on the balance sheet. Conversely, employers with DC plans merely record their contributions to pension plans as an expense of operations; once the contribution is made, there is no additional liability for future benefits. Other factors may also contribute to the shift. According to Byrnes and Welch, DB plans are also negatively affected by increased foreign competition, by the increased cost of pensions resulting from 
retirees living longer, and by the increased cost of insuring these plans through the Pension Benefit Guarantee Corporation (Byrnes and Welch, 2004, 54-72). Caudill (2010) attributes some of the decline in pension funding to the increase in the costs of health insurance benefits and to high unemployment rates, noting that employers place less emphasis on retirement benefits when there is high unemployment.

Accounting for pensions continues to be impacted by many factors, including recent changes in U.S. and international accounting standards for pensions and by government regulations that impact pensions. Researchers, therefore, anticipate a continued decline in the number of DB plans.

This paper discusses the new rules for pension accounting under SFAS 158, particularly the provisions which increase the likelihood that plan sponsors will report a pension liability. Using a sample of Fortune 100 companies, this paper analyzes the effect of the initial implementation of SFAS 158 on reported pension assets and liabilities and tracks the reported pension disclosures through the recession of 2007 and 2008. The purpose of this paper is to determine if the combined influences of the new reporting standard and a weak economy have negatively affected the net pension position of large companies.

\section{REVIEW OF LITERATURE}

Pension accounting has been a controversial topic for many years. Beginning in 1973, the Financial Accounting Standards Board (FASB) initiated its study of pension accounting. Following years of study, the FASB implemented major changes with SFAS 87, Employer's Accounting for Pensions in 1985, and implemented additional requirements with SFAS 132, Employers' Disclosures about Pensions and Other Postretirement Benefits (revised in 2003). In response to concerns over these standards, FASB issued SFAS 158, Employers' Accounting for Defined Benefit Pension and Other Postretirement Plans in September 2006. Recently, the International Accounting Standards Board (IASB) issued a proposal, which could modify pension reporting under international standards by 2013. The paragraphs below summarize key provisions of the pension standards and summarize recent studies related to accounting for pensions.

\section{Accounting Standards Prior to 2006}

Under SFAS 87 (FASB, 1985), a company with a DB pension plan reported part of its underfunded pension obligations on the balance sheet. Referred to as the "minimum liability," the amount was calculated as the amount by which the accumulated benefit obligation (ABO) exceeded plan assets. By definition, the $\mathrm{ABO}$ is a relatively conservative measure of pension obligations, calculated with current salary levels rather than projected future salaries. Under SFAS 87, some information about the more realistic projected benefit obligation (PBO) was disclosed in the footnotes. SFAS 132-R (FASB, 2003) expanded the footnote disclosures, but many critics still found these disclosures inadequate.

Under SFAS 87, pension expense included (among other things) amortization of unexpected gains and losses on plan assets and amortization of unexpected changes in the actuarial value of benefit obligations, using a corridor approach. Pension expense also included amortization of prior service costs. Unamortized balances related to these elements were not reported.

FASB later found concerns that disclosures under SFAS 87 and SFAS 132-R did not adequately explain the funded status of DB plans. Specifically, a company did not report the actual overfunded or underfunded status of a DB plan on the balance sheet. While prior standards included additional information about the funded status in the notes to financial statements, the Board believed that users of financial statements find pension disclosures difficult to assess (FASB, 2006, 54-55).

Recent studies agree with the need for modification of the accounting standards. Bepristis and Xu (2006) assert that pension accounting under SFAS 87 and SFAS 132-R presented many problems, especially after the stock market collapse following the terrorist attacks of September 11, 2001. Under the old pension accounting regulations, investors could easily misinterpret a company's true financial situation. Investors could not determine the true financial position of a company by simply reviewing its financial statements because pension assets inflated net 
income. As an example, Bepristis and Xu point out that in 2001 Verizon Communications reported $\$ 389$ million in net income, including $\$ 1,320$ million of income related to pension plans. Without the pension-related income, Verizon would have reported a net loss (Bepristis and Xu, 2006, 296-297). Stickel and Tucker (2007) cite a similar example related to DuPont. In 2005, DuPont deferred certain pension costs, converting a $\$ 3.1$ billion pension deficit into a $\$ 2.3$ surplus (Bepristis and $\mathrm{Xu}, 2006,83$ ). Such extreme examples supported the need for reform in the generally accepted accounting standards for DB pension plans.

\section{Statement of Financial Accounting Standard 158}

SFAS 158 concludes the first phase of the FASB's comprehensive study of accounting for DB pension plans. According to FASB, the objective of the new standard is to improve reporting by requiring a business to recognize the overfunded or underfunded status of a DB plan as an asset or liability on the balance sheet, to recognize changes in the funded status as a component of comprehensive income, and to calculate the funded status as of the balance-sheet date (FASB, 2006, 1). Under the new standard, a balance sheet liability is reported when the amount of the projected benefit obligation (PBO) exceeds plan assets. An asset is reported when plan assets exceed the PBO. Also, under the new standard, the unamortized amounts related to unexpected gains and losses and prior service costs are included in other comprehensive income.

\section{Pension Protection Act of 2006}

Changes in government regulation of corporate pension plans impact choices employers make regarding pension plans. The Pension Protection Act (PPA) of 2006 contains many provisions that effect employer sponsored pension plans, producing the most comprehensive changes in pension law in over 30 years (Guerriero, 2009). Among its many provisions, the PPA should improve traditional pension plans in the U.S. by requiring better funding by employers (Landsberg, 2008) and should increase employer accountability for DB plans (Lucas, 2009). The PPA also included provisions related to new DB structures, which had a delayed implementation date of January 1, 2010 (Caudill, 2010). The PPA also allows quicker investment of corporate payments to DC retirement plans (Powers, 2007, 1).

Furdek and Lucas (2011) studied the impact of the PPA on pension obligations. Based on the results of their simulation, they concluded that the provisions of the PPA may lead to increased discount factors that could result in a reduction of the pension liabilities.

\section{Studies of the Impact of SFAS 158}

Early studies, which were conducted as companies prepared to implement SFAS 158, indicated that changes in pension accounting standards would significantly affect American businesses. According to Towers Perrin (2006), implementation of the new accounting rules "could erase $\$ 180$ billion in shareholders' equity for the Fortune 100 companies" (Towers Perrin, 2006, 2). PriceWaterhouseCoopers (2007) speculated that the new standards will lead companies to stop offering DB plans altogether (PWC, 2007, 7). According to Stickel and Tucker (2007), SFAS 158 could cause a decrease in stockholder's equity, will negatively affect accounting ratios that use equity as a variable, and, thereby, will affect debt lending (Stickel and Tucker, 2007, 83-84).

Anticipating the changes required by SFAS 158, Apostolou and Crumbley (2006) studied eight large companies with DB plans. Footnote disclosures indicated that five of the companies had underfunded pension plans in 2005, but none of these companies reported pension liabilities on their balance sheets.

Later studies have looked more extensively at the decreasing number of DB plans. Milevsky and Song (2010) studied the announcement effect of publicly traded companies that froze or partially froze DB plans, citing such actions by GM, Whirlpool, IBM, DuPont, Sprint Nextel, NCR, and Citigroup in 2006. According to Milevsky and Song, there continues to be a shift from DB to DC plans and the market reacts positively to such a shift. 


\section{IASB Proposal}

In April 2010, the IASB published an exposure draft outlining proposed changes to existing international accounting standards for DB pension plans (IASB, 2010). The comment period for this proposal ended in September 2010. Initially, the IASB proposed standards to eliminate the smoothing mechanisms in pension accounting, which defer recognition of changes in benefit obligations and plan assets. Based on early responses, however, the IASB modified this controversial change and put forth a compromise proposal that would recognize the volatile gains and losses in other comprehensive income rather that in net income.

Akresh and Stoler (2010) studied the comments submitted to the IASB and summarized that most stakeholders, including employers, accounting forms, and financial statement users, support the compromise proposal over the initial proposal. While some disagreement remains, some parts of the exposure draft are expected to be adopted by the IASB in the near future, then eventually adopted by the FASB.

\section{METHODOLOGY}

SFAS 158 makes significant changes in reporting the funded status of DB pension plans. Preliminary studies indicate that these changes will cause more companies to report pension liabilities on their statements of financial position. Publicly traded companies are required to apply the sections of SFAS 158 related to reporting funded status for fiscal years ending after December 15, 2006. This study analyzed a sample of large companies to determine the actual impact of implementation.

To obtain data related to implementation of SFAS 158 in 2006, a random sample of 20 companies was selected from the 2007 Fortune 100. Data for each company were obtained from the financial statements and related footnotes for 2005 and 2006. Each company's balance sheet and footnotes were analyzed to determine the types of pension plans offered, whether or not the company had implemented SFAS 158, and the reported pension asset or liability for companies with DB plans. Pension assets and liabilities were analyzed to determine the direction and amount of observed changes between 2005 and 2006. Following analysis of the affect of implementation, pension disclosures were tracked in a similar manner for three additional years through the ensuring economic downturn.

\section{ANALYSIS OF DATA}

All companies in the original sample offered post-retirement employee benefits. For the 20 companies selected, three (15\%) had DC plans, three (15\%) had DB plans, and $14(70 \%)$ had a combination of both. For purposes of this study, the three companies with DC plans only were eliminated, and pension disclosures for the remaining 17 companies were analyzed. Of the companies with DB plans, 16 of the 17 companies adopted SFAS 158 in the financial statements for fiscal year 2006. One company, Morgan Stanley, had a fiscal year ending on November 30, 2006 (prior to the effective date for SFAS 158) and did not adopt SFAS 158 until 2007.

\section{Changes in Pension Positions after SFAS 158}

The funded DB positions for the 17 companies are summarized in Table 1. Contrary to expectations, there was only a slight increase in the number of companies reporting pension liabilities after the implementation of SFAS 158. In 2005, 11 companies (65\%) reported a pension liability and in 2006, 12 (71\%) reported a pension liability. After implementing SFAS 158, two companies (Merrill Lynch and Coca-Cola) moved from an asset position to a liability position and one company (MetLife) moved from a liability position to an asset position.

Companies within the study varied widely in the amount of reported pension assets and pension liabilities. For the first year, pension funding positions ranged from an asset of over $\$ 1.9$ billion for Prudential Financial to a liability of $\$ 3$ billion for Proctor and Gamble. In the second year, the gap closed somewhat, ranging from an asset of $\$ 2.4$ billion for Prudential Financial to a liability of \$3 billion for Proctor and Gamble. 
Table 1: Funded Status of Defined Benefit Plans (2005 - 2006, In Millions)

\begin{tabular}{|c|c|c|c|c|}
\hline Company & FY 2005 & FY 2006 & Better Position & Worse Position \\
\hline Wal-Mart Stores & $(560)$ & $(459)$ & 101 & \\
\hline Merrill Lynch & 266 & (305) & & -296 \\
\hline Proctor and Gamble & $(3,054)$ & $(3,041)$ & 13 & \\
\hline State Farm Insurance & $(408)$ & $(453)$ & & -45 \\
\hline Target & 186 & 275 & 89 & \\
\hline Wellpoint & 54 & 171 & 117 & \\
\hline MetLife & $(1,334)$ & 346 & 1,680 & \\
\hline Wachovia & 159 & 848 & 689 & \\
\hline Sprint Nextel & $(550)$ & $(261)$ & 289 & \\
\hline Intel & $(224)$ & (339) & & -115 \\
\hline Sysco & (433) & $(99)$ & 334 & \\
\hline Prudential Financial & 1,854 & 2,427 & 573 & \\
\hline Hess & $(309)$ & $(251)$ & 58 & \\
\hline Comcast & $(96)$ & $(62)$ & 34 & \\
\hline $\mathrm{HCA}$ & (42) & (199) & & -157 \\
\hline Coca-Cola & 151 & $(203)$ & & -354 \\
\hline Morgan Stanley & $(307)$ & $(251)$ & 56 & \\
\hline
\end{tabular}

Analysis of the changes between 2005 and 2006 are contrary to what was expected following the implementation of SFAS 158. Only 5 of the 17 companies (29\%) experienced deterioration in the reported funding status. Of these companies, one reported a change from an asset position to a liability position, and four reported an increased liability. Furthermore, the average pension position for the selected companies improved from a $\$ 273$ million liability to a $\$ 109$ million liability, a $60 \%$ decrease in the average liability. Analysis of the 12 companies with a better pension position in 2006 indicates an average improvement of $\$ 336$ million; while analysis of the 5 companies with a worse pension position shows an average decrease of \$193 million.

In summary, the adoptive effects of SFAS 158 do not appear to have the immediate negative effect on reported pension positions that were anticipated.

\section{Longitudinal Analysis of Net Pension Positions}

The pension disclosures for the 17 companies were tracked over a five-year period (2005-2009) at which time three companies dropped from the study. One company, HCA, went private in 2006; one company, Wachovia, was absorbed in a merger, and one company, State Farm Insurance, did not provide historical public financial statements. The net pension positions for the companies are summarized in Table 2 on the following page.

Table 2: Funded Status of Defined Benefit Plans (2005 - 2009, In Millions)

\begin{tabular}{|c|c|c|c|c|c|}
\hline Company & FY 2005 & FY 2006 & FY 2007 & FY 2008 & FY 2009 \\
\hline Wal-Mart Stores & $(560)$ & $(459)$ & $(197)$ & $(323)$ & $(588)$ \\
\hline Merrill Lynch & 266 & (305) & 352 & 868 & 616 \\
\hline Proctor and Gamble & $(3,054)$ & $(3,041)$ & $(2,469)$ & $(2,870)$ & $(3,706)$ \\
\hline Target & 186 & 275 & 348 & $(213)$ & $(103)$ \\
\hline Wellpoint & 54 & 171 & 350 & $(233)$ & $(48)$ \\
\hline MetLife & $(1,334)$ & 346 & 775 & $(482)$ & $(879)$ \\
\hline Sprint Nextel & $(550)$ & $(261)$ & $(217)$ & $(805)$ & $(403)$ \\
\hline Intel & $(224)$ & (339) & $(310)$ & $(473)$ & $(257)$ \\
\hline Sysco & (433) & (99) & $(26)$ & $(108)$ & (308) \\
\hline Prudential Financial & 1,854 & 2,427 & 2,095 & 1,657 & 736 \\
\hline Hess & (309) & $(251)$ & $(208)$ & $(545)$ & $(475)$ \\
\hline Comcast & $(96)$ & $(62)$ & $(22)$ & $(29)$ & $(8)$ \\
\hline Coca-Cola & 151 & (203) & $(85)$ & $(1,328)$ & (964) \\
\hline Morgan Stanley & $(307)$ & $(251)$ & $(150)$ & $(80)$ & $(224)$ \\
\hline
\end{tabular}


Over the period 2005-2009, the number of companies with net pension liabilities increased. As shown in Table 3, nine of the 14 companies (64\%) reported a net pension liability in 2005. By 2009, 12 of the 14 companies (86\%) reported net pension liabilities.

Table 3: Companies with Net Pension Assets versus Net Pension Liabilities (2005 - 2009)

\begin{tabular}{|l|c|c|c|c|c|}
\hline \multicolumn{1}{|c|}{ Company } & FY 2005 & FY 2006 & FY 2007 & FY 2008 & FY 2009 \\
\hline $\begin{array}{l}\text { Number of companies with net } \\
\text { pension assets }\end{array}$ & 5 & 4 & 5 & 2 & 2 \\
\hline $\begin{array}{l}\text { Number of companies with net } \\
\text { pension liabilities }\end{array}$ & 9 & 10 & 9 & 12 & 12 \\
\hline
\end{tabular}

Changes in the number of plans with pension liabilities are most likely associated with the economic decline during the period. In mid 2008 the U.S. economy entered a recession and, in September 2008, the U.S. and world financial markets experienced a meltdown in prices. The S\&P 500 ended the year down $37 \%$, and the MSCI EAFE index of foreign stocks ended the year down 43\%. The market continued to decline in the first quarter of 2009 with U.S indices reaching their low point in March 2009. This was followed by a quick rebound in stock markets around the world though the worldwide recession began what is described as an anaemic recovery.

Furthermore, the net pension positions for the 14 companies with complete data deteriorated through 2009. As summarized in Table 4, the net pension position of 8 of the 14 companies (57\%) deteriorated between 2005 and 2009. Prudential Financial and Coca-Cola reported the most deterioration; each lost over $\$ 1$ billion in net pension value. Both companies showed a net pension asset in 2005, but the losses moved Coca-Cola to a net pension liability position in 2009. For the six companies that did not experience a decline in pension position between 2005 and 2009, only Merrill Lynch was able to maintain a net pension asset position through the recession.

Table 4: Change in Funded Status of Defined Benefit Plans (2005 to 2009, In Millions)

\begin{tabular}{|l|c|c|c|c|}
\hline \multicolumn{1}{|c|}{ Company } & FY 2005 & FY 2009 & Better position & Worse position \\
\hline Wal-Mart Stores & $(560)$ & $(588)$ & & -28 \\
\hline Merrill Lynch & 266 & 616 & 350 & -652 \\
\hline Proctor and Gamble & $(3,054)$ & $(3,706)$ & & -289 \\
\hline Target & 186 & $(103)$ & & -102 \\
\hline Wellpoint & 54 & $(48)$ & & \\
\hline MetLife & $(1,334)$ & $(879)$ & 455 & 147 \\
\hline Sprint Nextel & $(550)$ & $(403)$ & & -33 \\
\hline Intel & $(224)$ & $(308)$ & 125 & -1118 \\
\hline Sysco & $(433)$ & 736 & & -166 \\
\hline Prudential Financial & 1,854 & $(475)$ & & \\
\hline Hess & $(309)$ & $(8)$ & & \\
\hline Comcast & $(96)$ & $(964)$ & & \\
\hline Coca-Cola & 151 & $(224)$ & & \\
\hline Morgan Stanley & $(307)$ & & & \\
\hline Note: pension liabilities are indicated with parentheses. & \\
\hline
\end{tabular}

In summary, the economic meltdown of 2008 and 2009 most certainly contributed to the noted deterioration in the pension positions for the companies studied. We are unable to separate the effects of the economic meltdown with the effects of SFAS 158 and, therefore, draw no conclusions as to the effects of SFAS 158 for this period.

\section{CONCLUSION}

SFAS 158 requires calculation of the net pension asset or liability using the higher PBO rather than the more conservative obligation measured as the ABO. However, the overall impact of this change is not apparent in 
the change in the average pension position, in the increase in the number of companies reporting pension liabilities, or in the number of companies reporting deterioration in funding status related to pension plans. To minimize the impact of SFAS 158, companies may have changed other assumptions within the obligation calculation or increased pension funding to minimize the impact of adopting SFAS 158.

With many Americans reaching retirement age and the state of pensions in question, more standards and regulations may be needed to ensure both the financial security of pension plans and the reliability and relevance of pension disclosures. The FASB has stated that SFAS 158 is the result of phase one of the Board's study of pension accounting. Phase two is intended to focus on additional issues, including convergence with international standards (Miller and Bahnson, 2007, 37). Furthermore, the SEC, CFA Institute, and the Financial Accounting Standards Advisory Council (FASAC) are currently demanding a more comprehensive improvement to the existing GAAP (Miller and Bahnson, 2007, 42). The conclusion of these studies may help improve financial reporting, as well as address the substantive issues related to the financial stability of pension plans.

Additional research is needed to better understand the impact of SFAS 158 on financial reporting, including studies of a larger sample of companies. Additional research is also needed to identify areas for increased scrutiny and improvement related to pension accounting. As more is learned about the impact of SFAS 158, stronger conclusions may become apparent regarding the viability of DB pension plans as a component of employee benefits.

\section{AUTHOR INFORMATION}

Terrye A. Stinson is the Blanchard Professor of Accounting at Southern Arkansas University. She earned her DBA from Louisiana Tech University. Stinson is a certified public accountant and a former member of the Arkansas State Board of Public Accountancy. E-mail: tastinson@ saumag.edu

J. David Ashby is the Peoples Bank Professor of Economics and Finance at Southern Arkansas University. He earned his DBA from Louisiana Tech University. Ashby is a certified public accountant and a certified financial planner. E-mail: jdashby@ saumag.edu

Kimberly Shirey is a graduate of Southern Arkansas University and recently joined the accounting staff of Murphy Oil Corporation. E-mail: kmfrisby7655@stumail.saumag.edu

\section{REFERENCES}

1. Akresh, M. \& K. Stoler. (2010). Pension accounting: New solution for an old dilemma? Financial Executive, 26(9), 28-32.

2. Apostolou, N. \& D. Crumbley. (2006). New pension accounting rules: Defusing the retirement time bomb. The CPA Journal, 76(11), 22-26.

3. Bepristis, M. \& Y. Xu. (2006). Defined benefit pension fund accounting: Relevancy, clarity, and consistency. Journal of American Academy of Business, 9(2), 294-299.

4. $\quad$ Byrnes, N. \& D. Welch. (2004, July 19). The benefits trap. Business Week, 54-72.

5. Caudill, A. (2010). The 2010 DB-K: A plan for the future? Journal of Financial Service Professionals, 64(1), 39-41.

6. Dennis, A. (2006). Understanding the best and the brightest. Journal of Accountancy, 202(5), 41-47.

7. Financial Accounting Standards Board. (1985). Employers' Accounting for Pensions. Statement of Financial Accounting Standards No. 87. Norwalk, CT: Financial Accounting Standards Board.

8. Financial Accounting Standards Board. (2003). Employers' Disclosures about Pensions and Other Postretirement Benefits - an amendment of FASB Statements 87, 88, and 106. Statement of Financial Accounting Standards No. 132-R. Norwalk, CT: Financial Accounting Standards Board.

9. Financial Accounting Standards Board. (2006). Employers' Accounting for Defined Benefit Pension and Other Postretirement Plans. Statement of Financial Accounting Standards No. 158. Norwalk, CT: Financial Accounting Standards Board.

10. Furdek, J.M. \& J. Lucas. (2011). Will the Pension Protection Act protect defined benefit pensions? Journal of Pension Planning and Compliance, 37(1), 1-9. 
11. Guerriero, E. J. (2009). Pension Protection Act of 2006: Effects on defined-benefit plans. Journal of Financial Service Professionals, 63(2), 58-70.

12. International Accounting Standards Board. (2010) Defined Benefit Plans, Proposed Amendments to AIS 19, Exposure Draft ED/10/3.

13. Kozol, G. (2011). Boomer business owners: Time for a new plan. Journal of Financial Service Professionals, 65(1), 37-40.

14. Landsberg, R.D. (2008). An overview of the Pension Protection Act of 2006. Journal of Pension Planning and Compliance, 33(4), 22-42.

15. Lucas, J. (2009). Did the Pension Protection Act (PPA) of 2006 resolve the pension crisis in corporate America? American Journal of Business Education, 2(4), 1-5.

16. Milevsky, M.A. \& K. Song. (2010). Do markets like frozen defined benefit pensions? An event study. The Journal of Risk and Insurance, 77(4), 893-909.

17. Miller, P. \& P. Bahnson. (2007). Perfect storm prompts changes in pension accounting. Journal of Accountancy, 203(5), 36-42.

18. Powers, K. (2007). The Pension Reform Act's long arm: New law affects BOLI, pensions, and more. Crowe Chizek and Company LLC. Retrieved October 22, 2007 from http://www.pwc.com/extweb/pwcpublications.nsf/docid/130848181CEF96068525718D00710F63/\$FILE/p ension-paper.pdf.

19. PricewaterhouseCoopers, LLP. (2007) Rethinking postretirement benefits. Retrieved October 18, 2007 from http://www.pwc.com/extweb/pwcpublications.nsf/docid/130848181CEF96068525718D00710F63/\$FILE/p ension-paper.pdf.

20. Stickel, S. \& J. Tucker. (2007). New accounting rules for defined-benefit pension plans: Impact and fallout. Journal of Financial Service Professionals, 61(1), 81-88.

21. Towers Perrin. (2006). New pension accounting could significantly affect companies' financial statements. Pension Benefits, 2-4. 